This is the final peer-reviewed accepted manuscript of:

Chiocchio I., Mandrone M., Sanna C., Maxia A., Tacchini M., Poli F. - Screening of a hundred plant extracts as tyrosinase and elastase inhibitors, two enzymatic targets of cosmetic interest. Industrial Crops and Products, 122, 498-505, 2018.

The final published version is available online at: https://doi.org/10.1016/i.indcrop.2018.06.029

Rights / License: CCBY

The terms and conditions for the reuse of this version of the manuscript are specified in the publishing policy. For all terms of use and more information see the publisher's website.

This item was downloaded from IRIS Università di Bologna (https://cris.unibo.it/)

When citing, please refer to the published version. 


\section{Screening of a hundred plant extracts as tyrosinase and elastase inhibitors, two enzymatic targets of cosmetic interest}

Chiocchio I. ${ }^{\mathrm{a}}$, Mandrone M. ${ }^{\mathrm{a},}$, Sanna C. ${ }^{\mathrm{b}}$, Maxia A. ${ }^{\mathrm{b}}$, Tacchini M. ${ }^{\mathrm{c}}$, Poli F. ${ }^{\mathrm{a}}$

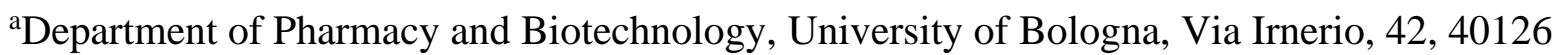

Bologna, Italy

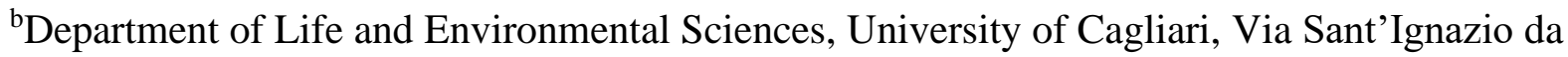
Laconi 13, 09123, Cagliari, Italy

${ }^{\mathrm{c}}$ Department of Life Sciences and Biotechnology, University of Ferrara, via Borsari 46, 44100 Ferrara (Italy)

\section{*Correspondence}

Dr. Manuela Mandrone, University of Bologna, Department of Pharmacy and Biotechnology, Via Irnerio 42, 40126 Bologna, Italy

E-mail: manuela.mandrone2@unibo.it Phone: +390512091294; Fax +39051242576

This item was downloaded from IRIS Università di Bologna (https://cris.unibo.it/)

When citing, please refer to the published version. 


\begin{abstract}
In search for natural products of cosmetic interest, a hundred plant extracts were in vitro tested against elastase and tyrosinase. The inhibitors of these enzymes find application as skin whitening, antiageing, anti-wrinkle agents as well as in the treatment of dermatological disorders.
\end{abstract}

Among the tested samples, seventeen extracts resulted strongly active. In particular, eleven out of them were capable to inhibit both enzymes, five showed a strong activity only against tyrosinase and one only against elastase. The $\mathrm{IC}_{50}$ values of the selected samples ranged from 7 to $100 \mu \mathrm{g} / \mathrm{mL}$ and from 20 to $100 \mu \mathrm{g} / \mathrm{mL}$ against elastase and tyrosinase, respectively. Leaves extract of Pistacia lentiscus emerged as the most potent elastase inhibitor and, together with Cytinus hypocistis (aerial parts) and Limonium morisianum (aerial parts), it showed also the lowest $\mathrm{IC}_{50}$ of tyrosinase inhibition.

The tested plants were collected in India, Africa and Mediterranean area. Interestingly, among the most active ones, two are endemic and exclusive of Sardinia Island (Italy), namely: Limonium morisianum and Hypericum scruglii, moreover, the latter resulted the only plant which hydroalcoholic extract was capable to inhibit elastase selectively.

Moreover, a positive correlation was established among the potency of enzymatic inhibitions and the total phenolic and flavonoid content of the samples. The presence of these aromatic compounds in the most active plants confers them a potential additional value as skin protectors from oxidative damage.

This item was downloaded from IRIS Università di Bologna (https://cris.unibo.it/)

When citing, please refer to the published version. 


\section{Keywords}

Skin ageing, tyrosinase, elastase, phytocosmetics, polyphenols, Hypericum scruglii

\section{Introduction}

Skin ageing processes are generally divided into intrinsic and extrinsic, both responsible for drastic changes in skin structure and elasticity. The intrinsic or chronological skin ageing is irremediably related to the passage of time, although it is also influenced by the inherited genes. Conversely, the extrinsic skin ageing is caused by environmental factors, such as chronic exposure to sunlight (photoageing) or pollutants, and it is influenced by miscellaneous lifestyle components (i.e. smoking and diet) (Farage et al., 2008). In particular, photoageing is caused by overexposure to UV radiations, which increases the production of reactive oxygen species (ROS) (Rittié and Fisher, 2002), causing lipid peroxidation, DNA damage, and proteins alterations. Moreover, ROS can also contribute to skin ageing by direct activation of enzymes responsible for the cleavage of extracellular matrix (ECM) components (Mukherjee et al., 2011; Rittié and Fisher, 2002).

Natural products from plants are widely used as cosmetic or cosmeceutical ingredients because of their capability to slow down the intrinsic skin ageing processes and to contrast the extrinsic ones. Plants anti-ageing properties are generally attributed to their antioxidant metabolites, which minimize free radical activity and protect skin against solar radiations (Sahu et al., 2013). Additionally, several plant metabolites are also reported to modulate the activity of enzymes involved in the ageing processes (Cefali et al., 2016; Mukherjee et al., 2011). Among these enzymatic targets of cosmetic interest, elastase and tyrosinase are of remarkable importance.

This item was downloaded from IRIS Università di Bologna (https://cris.unibo.it/)

When citing, please refer to the published version. 
Elastase belongs to chymotrypsin family of proteases and it is responsible for the breakdown of elastin and other proteins, such as collagen and fibronectin, which are fundamental for the ECM elastic properties (Imokawa and Ishida, 2015). Misregulations of this enzyme are involved in skin ageing processes (Korkmaz et al., 2010). In fact, the excessive hydrolysis of the dermal elastin fiber network leads to the loss of skin elasticity and consequent skin sagging (Thring et al., 2009). On this basis, elastase inhibitors are endowed with anti-wrinkles activity promoting the preservation of skin elasticity.

Tyrosinase is a copper-containing enzyme, also known as polyphenol oxidase (PPO). It catalyzes two distinct reactions, namely: the hydroxylation of a monophenol and the conversion of an $o$-diphenol to the corresponding $o$-quinone. This enzyme is responsible for the rate-limiting first two steps of melanin biosynthetic pathway, and thus, for skin, hair, and eyes color in humans (Pillaiyar et al., 2017). Tyrosinase misregulated expression and/or activity causes skin pigmentation disorders such as: lentigo senilis, urticaria pigmentosa, and age-related skin hyperpigmentation (Slominski et al., 2004). Therefore, tyrosinase inhibitors are candidate skin-whitening agents.

In this work, aimed at identifying natural products endowed with anti-ageing potential, the in vitro tyrosinase and elastase inhibitory activity of a hundred hydroalcoholic plant extracts was evaluated. Moreover, the total phenolic and flavonoid content of the tested extracts was also determined, considering the importance of these compounds as antioxidants. In order to investigate on the involvement of these classes of phytochemicals in the tested bioactivities, total phenolic and flavonoid content was also statistically correlated to the percentages of enzymatic inhibitions.

\section{Methods and materials}

\subsection{Plant material}

This item was downloaded from IRIS Università di Bologna (https://cris.unibo.it/)

When citing, please refer to the published version. 
The Indian plants (used in Ayurveda tradition), dried and powdered, were kindly supplied by Maharishi Ayurveda Product Italy (Verona, Italy). They were collected in Ram Bagh (Rajasthan, India) and authenticated by Dr. MR Uniyal, Maharishi Ayurveda Product Ltd., Noida, India.

The samples of African plants were collected in six villages of Baskoure and Songretenga communes (Burkina Faso) and identified by Prof. Joseph Issaka Boussim. Among the Mediterranean plants, the ones collected in Sardinia Island (Italy) were identified by Dr. Cinzia Sanna and Prof. Andrea Maxia, while the two Sedum species were collected in Emilia Romagna (Italy) and identified by Prof. Ferruccio Poli. The other Mediterranean plants samples were kindly supplied by Biokyma S.r.l, Anghiari (AR) Italy, and identified by Dr. Franco Maria Bini. Vouchers of crude drugs of the Indian plants and Mediterranean plants were deposited in Department of Pharmacy and Biotechnology, University of Bologna (Via Irnerio 42, Bologna, Italy). Vouchers of the African plants were deposited in Herbarium of the Botanical Laboratory of the University of Ouagadougou (Burkina Faso). Vouchers of the Sardinian plants were deposited at the General Herbarium of the Department of Life and Environmental Sciences, University of Cagliari and vouchers of the two Sedum species were deposited in the Herbarium of the Department of Pharmacy and Biotechnology, University of Bologna. All the information (including vouchers) of the considered plants are reported in Table 1.

\subsection{Preparation of the extracts}

Thirty mg of dried and powdered plant material were extracted by sonication for 30 minutes using $1.5 \mathrm{~mL}$ of $\mathrm{MeOH} / \mathrm{H}_{2} \mathrm{O}(1: 1)$. Subsequently, the samples were centrifuged for $20 \mathrm{~min}$, the supernatant was separated from the pellet and dried to yield the crude extracts.

\subsection{Tyrosinase inhibitory assay}

This item was downloaded from IRIS Università di Bologna (https://cris.unibo.it/)

When citing, please refer to the published version. 
The enzymatic inhibitory assay was performed according to Venditti et al. (2013) with slight modifications. Mushroom tyrosinase $(2 \mathrm{mU})$ and sample $(50 \mu \mathrm{g} / \mathrm{mL})$ were incubated for $5 \mathrm{~min}$ in 0.1 M sodium phosphate buffer $\mathrm{pH} 6.8$, in $0.1 \mathrm{~mL}$ of final volume. L-DOPA (final concentration $2 \mathrm{mM}$ ) was added up to a final reaction volume of $0.2 \mathrm{~mL}$. The formation of dopachrome was immediately monitored for $5 \mathrm{~min}$ at $490 \mathrm{~nm}$ in a microplate reader (Victor ${ }^{\mathrm{TM}} X 3$ PerkinElmer, Waltham, Massachusetts, United States) under constant temperature of $30^{\circ} \mathrm{C}$. The $\mathrm{IC}_{50}$ (concentration necessary for $50 \%$ inhibition of enzyme activity) was calculated by constructing a linear regression curve showing extracts concentrations (from 1 to $250 \mu \mathrm{g} / \mathrm{mL}$ ) on the $x$-axis and percentage inhibition on the $y$-axis. A negative control was obtained by adding water instead of extracts, while kojic acid (solubilized in water) was used as positive control, finding an $\mathrm{IC}_{50}$ of $3 \pm 0.37 \mu \mathrm{g} / \mathrm{mL}(21 \mu \mathrm{M})$.

The percentage of enzyme inhibition was calculated using the following formula:

$\%$ Inhibition $=\left[1-\left(\Delta \mathrm{Abs} / \mathrm{min}_{\text {sample }} / \Delta \mathrm{Abs} / \mathrm{min}_{\text {negative control }}\right) \times 100\right]$

In order to determine the kinetic parameters for the enzymatic reaction the Lineweaver-Burk plot was built, using substrate concentration in the range from 0.5 to $4 \mathrm{mM}$. In the assay conditions, the obtained $\mathrm{K}_{\mathrm{M}}$ value was of $0.2 \mathrm{mM}$ and $\mathrm{V}_{\max }$ of $10 \mu \mathrm{mol} / \mathrm{min}(\Delta \mathrm{Abs} / \mathrm{min}=0.03)$, considering dopachrome $\varepsilon$ at $490 \mathrm{~nm}=3.6201 \mathrm{mM}^{-1} \mathrm{~cm}^{-1}$ and a light path length of $0.8 \mathrm{~cm}$.

\subsection{Elastase inhibitory assay}

The assay was performed according to the method of Liyanaarachchi et al. (2018) whit some modifications. Porcine pancreatic elastase $(1.5 \mathrm{mU})$ and extract sample $(50 \mu \mathrm{g} / \mathrm{mL})$ were incubated for $5 \mathrm{~min}$ in $0.1 \mathrm{M}$ TRIS buffer $\mathrm{pH} 8.1$, in $0.1 \mathrm{~mL}$ final volume. Substrate N-succinyl-Ala-Ala-ProPhe p-nitroanilide $(2 \mathrm{mM})$ was added to start the reaction in a final volume of $0.2 \mathrm{~mL}$. The variation of absorbance was monitored for $5 \mathrm{~min}$ at $420 \mathrm{~nm}$ in the microplate reader under constant temperature

This item was downloaded from IRIS Università di Bologna (https://cris.unibo.it/)

When citing, please refer to the published version. 
of $30^{\circ} \mathrm{C}$. For the $\mathrm{IC}_{50}$ calculations, samples and quercetin (positive control) were tested at different concentrations ranging from 1 to $250 \mu \mathrm{g} / \mathrm{mL}$. In the case of quercetin the assay was performed in $2 \%$ DMSO, thus a proper negative control in the same conditions was used for the $\mathrm{IC}_{50}$ calculation.

Lineweaver-Burk plot was built, using substrate concentration in the range of $0.25-2 \mathrm{mM}$. In the assay conditions, the obtained $\mathrm{K}_{\mathrm{M}}$ value was of $0.2 \mathrm{mM}$ and $\mathrm{V}_{\max }$ of $6 \mu \mathrm{mol} / \mathrm{min}(\Delta \mathrm{Abs} / \mathrm{min}=0.04)$, considering $\varepsilon$ of p-nitroanilide at $420 \mathrm{~nm}=8.8 \mathrm{mM}^{-1} \mathrm{~cm}^{-1}$ and a light path length of $0.8 \mathrm{~cm}$.

\subsection{Total phenolic and flavonoid content}

The assays were performed in Spectrophotometer Jasco V-530 as described by Di Pompo et al. (2014) with slight modifications. Briefly, for total phenolic content analysis a calibration curve was constructed using $50 \mu \mathrm{L}$ of different gallic acid stock solutions prepared in $\mathrm{MeOH} 80 \%$ (from 10 to $200 \mu \mathrm{g} / \mathrm{mL}$ ) mixed with $250 \mu \mathrm{L}$ of Folin-Ciocalteu reagent (diluted 1:10) and $500 \mu \mathrm{L}$ of $\mathrm{H}_{2} \mathrm{O}$. Different stock solutions of extracts were prepared in water (from 0.05 to $0.2 \mathrm{mg} / \mathrm{mL}$ ) and $50 \mu \mathrm{L}$ of each stock were mixed with the same reagents as described above. Both calibration curve and samples were incubated at room temperature for $5 \mathrm{~min}$ before adding $800 \mu \mathrm{L}$ of sodium carbonate solution $\left(\mathrm{Na}_{2} \mathrm{CO}_{3} 20 \%\right)$. After $30 \mathrm{~min}$ of incubation at $40^{\circ} \mathrm{C}$, absorption was recorded at $760 \mathrm{~nm}$. Total phenolic content was calculated by interpolation in the calibration curve and expressed as: mg GAE (gallic acid equivalent)/g of extract (dried weight).

Total flavonoid content was determined using rutin to perform the calibration curve. Different stock solutions of extracts were prepared in water (from 0.05 to $0.2 \mathrm{mg} / \mathrm{mL}$ ) and $50 \mu \mathrm{L}$ of each one were mixed with $450 \mu \mathrm{L}$ of methanol and $500 \mu \mathrm{L}$ of $\mathrm{AlCl}_{3}(2 \%$ w/volume of methanol). The absorption at $430 \mathrm{~nm}$ was recorded after incubation $(15 \mathrm{~min})$ at room temperature. The calibration curve was obtained using $50 \mu \mathrm{L}$ of different rutin stock solutions prepared in DMSO (from 1 to $100 \mu \mathrm{g} / \mathrm{mL}$ ).

This item was downloaded from IRIS Università di Bologna (https://cris.unibo.it/)

When citing, please refer to the published version. 
Total flavonoid content of the extracts was calculated by interpolation in the calibration curve and expressed in terms of $\mathrm{mg} \mathrm{RE}$ (rutin equivalent)/g of extract (dried weight).

\subsection{Statistical analysis}

Values were expressed as the mean \pm SD of three independent experiments (each one performed in duplicate). Statistical analyses were performed using Graph Pad Prism 4 software (La Jolla, CA, USA). Samples were compared by one-way analysis of variance (ANOVA), followed by Tukey's honestly significant difference (HSD) post-hoc test, considering significant differences at $P$ values $<0.05$. Pearson correlation coefficient $(r)$ was evaluated in order to determine the correlation between total phenolic and flavonoid content and enzymatic activities.

\section{Results}

A first screening of tyrosinase and elastase inhibitory activity was carried out on the extracts at the fixed concentration of $50 \mu \mathrm{g} / \mathrm{mL}$. The obtained results (reported in Table 1) allowed the selection of seventeen extracts, which, at the tested concentration, highlighted a marked inhibitory activity (percentage of inhibition higher than 30\%). In particular, the following samples were selected:

Arbutus unedo L. (leaves), Azadirachta indica A. Juss. (leaves), Cistus monspeliensis L. (aerial parts), Cistus salvifolius L. (aerial parts), Cochlospermum tinctorium Perrier ex A. Rich. (leaves), Cytinus hypocistis (L.) L. (aerial parts), Hypericum hircinum L. (aerial parts), Hypericum scruglii Bacch., Brullo \& Salmeri (areal parts), Khaya senegalensis (Desv.) A. Juss (fruits), Limonium morisianum Arrigoni (aerial parts), Myrtus communis L. (fruits and leaves), Pistacia lentiscus L. (fruits and leaves), Pistacia terebinthus L. (leaves), Vitellaria paradoxa C.F. Gaertn. (leaves and roots).

Those samples were more deeply investigated by calculating the $\mathrm{IC}_{50}$ of enzymatic inhibition and comparing them by statistical analysis.

This item was downloaded from IRIS Università di Bologna (https://cris.unibo.it/)

When citing, please refer to the published version. 
Regarding elastase inhibition, the $\mathrm{IC}_{50}$ values of the twelve selected samples ranged from $7.17 \pm 1.36$ to $101.07 \pm 20.74 \mu \mathrm{g} / \mathrm{mL}$ (Fig. 1A). These results are particularly interesting considering that the positive control (quercetin) showed an $\mathrm{IC}_{50}$ value of $61 \mu \mathrm{g} / \mathrm{mL}(202 \mu \mathrm{M})$. Among the twelve samples, the extract obtained from the leaves of Pistacia lentiscus resulted the most potent elastase inhibitor.

Regarding the activity against tyrosinase, the $\mathrm{IC}_{50}$ values calculated for the sixteen most active extracts ranged from $20.35 \pm 0.24$ to $101.41 \pm 7.46 \mu \mathrm{g} / \mathrm{mL}$ (Fig. 1B). The extracts of Cytinus hypocistis (aerial parts), Limonium morisianum (aerial parts) and Pistacia lentiscus (leaves) resulted the most potent and no significant differences among their $\mathrm{IC}_{50}$ values were highlighted by the statistical analysis.

As highlighted by the results of the first screening (Table 1), three samples showed a percentage of tyrosinase inhibition little lower than $30 \%$, thus, although they were not selected among the most promising plants, their $\mathrm{IC}_{50}$ was also calculated. In particular, Cassia siberiana D.C. showed an $\mathrm{IC}_{50}$ of $165 \mu \mathrm{g} / \mathrm{mL}$, while Lavandula stoechas L. and Hypericum scruglii were proved only poorly active. In fact, for these two plants, even at the highest tested concentration $(250 \mu \mathrm{g} / \mathrm{mL})$ the percentage of inhibition was much lower than $50 \%$.

Polyphenols and flavonoids are considered important natural active principles and, in particular, they are well known for their antioxidant properties. In the present study, the total content of these classes of metabolites was evaluated in all the samples. The seventeen extracts, selected as more promising as enzymatic inhibitors, proved also enriched in flavonoids (ranging from $7.8 \pm 0.1$ to $86.6 \pm 0.9 \mathrm{mg}$ $\mathrm{RE} / \mathrm{g}$ of extract) and phenolics (ranging from $41.8 \pm 0.7$ to $147 \pm 1.4 \mathrm{mg} \mathrm{GAE} / \mathrm{g}$ of extract).

Moreover, considering that several polyphenols and flavonoids (i.e. chalcones, flavanones, resveratrol derivatives, ellagic acid) are reported to inhibit tyrosinase and elastase (Pillaiyar et al.,

This item was downloaded from IRIS Università di Bologna (https://cris.unibo.it/)

When citing, please refer to the published version. 
2017; Xing et al., 2016; Wittenauer et al., 2015), the relations between enzyme inhibitory activities and total phenolic and flavonoid content were statistically investigated.

In particular, Pearson correlation test was performed to correlate the percentage of enzymatic inhibition (showed by the extracts at $50 \mu \mathrm{g} / \mathrm{mL}$ ) to the phenolic and flavonoid content, respectively. Although the found correlations were not strong, in all cases $r$ was comprised between 0 and 1 , indicating a positive correlation between increasing total phenolic and flavonoid content and both enzymatic inhibitory activities (Fig. 2A and B). The highest positive correlation $(r=0.3535$ and $P=0.0003$ ) was found between tyrosinase inhibition and total phenolic content.

\section{Discussion}

In search for natural products endowed with elastase and tyrosinase inhibitory activity, a hundred plant extracts were in vitro tested against these two enzymes.

The samples were harvested in different geographical areas (Table 1), and the majority of them are plants of ethnobotanical relevance (Khare, 2014; Guarrera, 2006; Nadembega et al., 2011).

A documented ethnobotanical use is not available only for five out of the tested plants, namely: Centaurea horrida Badarò, Hypericum scruglii, Ferula arrigonii Bocchieri, Limonium morisianum and Plagius flosculosus (L.) S. Alavi \& V. H. Heywood, which are endemic plants of Sardinia Island (Italy).

Seventeen, out of a hundred samples, were selected as the most promising and their $\mathrm{IC}_{50}$ of enzymatic inhibition were investigated. Among them, eleven resulted strongly active on both enzymes; five were able to inhibit only tyrosinase and one was strongly active only against elastase. Leaves extract of Pistacia lentiscus emerged as the most potent elastase inhibitor and, together with Cytinus hypocistis

This item was downloaded from IRIS Università di Bologna (https://cris.unibo.it/)

When citing, please refer to the published version. 
(aerial parts) and Limonium morisianum (aerial parts), it showed also the lowest $\mathrm{IC}_{50}$ of tyrosinase inhibition.

P. lentiscus is used in Mediterranean traditional medicine in form of infusion or decoction to treat a wide number of diseases, such as stomachache, eyes infections, burn skin, bronchitis (Bouasla and Bouasla, 2017). Flavonoids, phenolic acids, and their derivatives such as myricetin glycoside, catechin, $\beta$-glucogallin, quercitrin gallate were identified as the most abundant phytoconstituents of this plant (Rodríguez-Pérez et al., 2013). Those compounds might play a role in the elastase inhibitory activity showed by this plant (Melzig et al., 2001). Interestingly, L. morisianum is an endemic and exclusive plant of Sardinia and recently some information about its phytochemical profile and anti HIV-1 activity were reported (Sanna et al., 2018a). Myricetin, myricetin 3-O-rutinoside, myricetin3-O-(6"-O-galloyl)- $\beta$-d-galactopyranoside, (-)-epigallocatechin 3-O-gallate, tryptamine, ferulic and phloretic acids were isolated from its aerial parts.

Some of the tested samples were obtained from plant species belonging to the same genus, this allowed further considerations concerning their bioactivities. In particular, according to the statistical analysis, Pistacia lentiscus leaves resulted more potent elastase inhibitor than leaves of Pistacia terebinthus $(P<0.05)$ (Fig. 1A), while no differences were found between their activity against tyrosinase (Fig. 2A). Cistus salvifolius was significantly more potent against elastase than Cistus monspeliensis, while, also in this case, no differences were found between their tyrosinase inhibitory activities. Hypericum hircinum was significantly more active against elastase than Hypericum scruglii $(P<0.05)$. Hypericum scruglii was found not active against tyrosinase, thus it is more promising to develop a cosmetic product endowed with selective anti-wrinkle activity.

H. scruglii resulted enriched in phloroglucinols, which were proved able to inhibit the HIV-1 replication in cell based assays (Sanna et al., 2018b).

This item was downloaded from IRIS Università di Bologna (https://cris.unibo.it/)

When citing, please refer to the published version. 
Moreover, Hypericum perforatum L. was also included in the initial screening, showing only a weak percentage of inhibition on both enzymes. In fact, it was not selected among the most active plants. The phytochemical profiles of these three Hypericum species were already reported to be significantly different; in the same study their inhibitory activity against $\alpha$-glucosidase was investigated and also in that case, $H$. perforatum proved to be less potent than the other two Hypericum species (Mandrone et al., 2017). The lack of cytotoxicity already reported for the hydroalcoholic extracts of these Hypericum species (Mandrone et al., 2017) make them even more promising for cosmetic purposes.

A further discussion deserved to be done also on the differences in bioactivity showed by extracts obtained from different organs of the same plant source (Table 1). In particular, both extracts of fruits and leaves of Myrtus communis were tested. Both fruits and leaves were active against tyrosinase, even though fruits resulted more active $(P<0.05)$ (Fig. 1B), and only fruits were found active against elastase. Conversely, whereas Arbutus unedo leaves exhibited remarkable elastase and tyrosinase inhibitory activities, no enzymatic inhibition was shown by the extract obtained from its fruits.

A. unedo is a source of arbutin, a glycosylate hydroquinone, which is already known as skinwhitening agent (Degen et al., 2016). However, it inhibits the monophenolase function of this enzyme (Hori et al., 2004), while, in this work, the inhibition of its diphenolase function was evaluated. This data suggests that the presence of active metabolites other than arbutin (i.e. flavonoids) (Castaldi et al., 2009) might contribute to A. unedo (leaves) anti-ageing and skin-whitening properties.

In the case of Pistacia lentiscus, fruits and leaves extracts were both strongly active against tyrosinase, with no significant differences in their $\mathrm{IC}_{50}$ values, while only leaves were found active against elastase.

This item was downloaded from IRIS Università di Bologna (https://cris.unibo.it/)

When citing, please refer to the published version. 
Roots and leaves of Vitellaria paradoxa were both selected among the most active samples, showing no significant differences between their $\mathrm{IC}_{50}$ values of tyrosinase and elastase inhibition (Fig. 1A and 1B). Vitellaria paradoxa is known as shea tree and it is very important for food and cosmetic industries. The most investigated and important product obtained from this plant is the butter extracted of the kernel, which is endowed with anti-inflammatory and antioxidant properties (Honfo et al., 2014). Saponins, tannins, and alkaloids were found in its roots, stem bark, and leaves even though these organs remain still poorly investigated (Ndukwe et al., 2007).

Phenolic and flavonoid content of all the samples was evaluated, and the plants selected as promising enzymatic inhibitors showed also to be enriched in these classes of natural compounds. These results suggest that the selected plants might have an additional value as skin protectors and anti-ageing agents, due to flavonoids and polyphenols antioxidant potential.

A linear correlation was found between enzymatic activities and increasing phenolic and flavonoid content. Specific class of polyphenols might act against tyrosinase through a competitive mechanism of inhibition, consistently with the biological role of this enzyme, which, in fact, is a polyphenoloxidase.

However, compounds, other than flavonoids and polyphenols, might be responsible for the activity against the considered enzymes, and further experiments are ongoing in order to acquire more information.

\section{Conclusions}

A hundred extracts obtained from plants collected in India, Africa and Mediterranean area were screened as elastase and tyrosinase inhibitors. Seventeen extracts were selected as the most promising, and among them eleven resulted strongly active on both enzymes; five were able to inhibit only

This item was downloaded from IRIS Università di Bologna (https://cris.unibo.it/)

When citing, please refer to the published version. 
tyrosinase and one was strongly active only against elastase. Noteworthy, among the most active plants selected, two are endemic of Sardinia Island, namely: Hypericum scruglii and Limonium morisianum.

The plants active against both enzymes are potentially suitable to develop skin-whitening agents, endowed with additional anti-wrinkles effect. In particular, the following 10 plants potently inhibited both enzymes: Arbutus unedo (leaves), Cistus salvifolius (aerial parts), Cistus monspeliensis (aerial parts), Cytinus hypocistis (aerial parts), Hypericum hircinum (aerial parts), Limonium morisianum (aerial parts), Pistacia terebinthus (leaves), Pistacia lentiscus (leaves), Myrtus communis (fruits), and Vitellaria paradoxa (leaves and roots).

Hypericum scruglii (aerial parts) resulted a strong and selective elastase inhibitor, suggesting its potential use as ingredient for selective anti-wrinkles cosmetics.

Azadirachta indica (leaves), Cochlospermum tinctorium (leaves), Khaya senegalensis (leaves), Myrtus communis (leaves) and Pistacia lentiscus (fruits) showed activity only against tyrosinase, resulting of particular interest to develop skin-whitening agents with no anti-wrinkle effect, eventually ideal for youngest skins.

Moreover, the most bioactive plants resulted also enriched in polyphenols and flavonoids, conferring them additional antioxidant properties. The total phenolic and flavonoid content showed a linear correlation with the enzymatic inhibitory activities. In order to identify the metabolites responsible for the activities, further biological and phytochemical studies are ongoing on the selected plants.

\section{Acknowledgements}

This item was downloaded from IRIS Università di Bologna (https://cris.unibo.it/)

When citing, please refer to the published version. 
Thanks are due to Dr. Luca Cornioli, Dr. Paolo Scartezzini and Dr. Pascal Nadembega for kindly providing part of the plants analyzed in this work. The authors thank Dr. Immacolata Maresca, Department of Life Sciences and Biotechnology, University of Ferrara, for technical assistance.

\section{Funding}

This work was partly supported by the grant 'Maria Grazia Cuccoli' from Fondazione Cassa di Risparmio di Bologna.

Declarations of interest: none

\section{References}

Bouasla, A., Bouasla, I., 2017. Ethnobotanical survey of medicinal plants in northeastern of Algeria. Phytomedicine.

Castaldi, S., Carfora, A., Fiorentino, A., Natale, A., Messere, A., Miglietta, F., Cotrufo, M.F., 2009. Inhibition of net nitrification activity in Mediterranean woodland: possible role of chemicals produced by Arbutus unedo. Plant Soil 315: 273-283.

Cefali, L.C., Ataide, J.A., Moriel, P., Foglio, M.A., Mazzola, P.G., 2016. Plant-based active photoprotectants for sunscreens. Int. J. Cosmetic Sci. 38:346-53.

Degen, G.H., 2016. Opinion of the Scientific Committee on Consumer safety (SCCS)-Opinion on the safety of the use of $\alpha$-arbutin in cosmetic products. Regul. Toxicol. Pharmacol. 74:75-76.

Di Pompo, G., Poli, F., Mandrone, M., Lorenzi, B., Roncuzzi, L., Baldini, N., Granchi, D., 2014. Comparative "in vitro" evaluation of the antiresorptive activity residing in four Ayurvedic medicinal

This item was downloaded from IRIS Università di Bologna (https://cris.unibo.it/)

When citing, please refer to the published version. 
plants. Hemidesmus indicus emerges for its potential in the treatment of bone loss diseases. J. Ethnopharmacol. 154:462-70.

Farage, M.A., Miller, K.W., Elsner, P., Maibach, H.I., 2008. Intrinsic and extrinsic factors in skin ageing: a review. Int. J. Cosmetic Sci. 30:87-95.

Guarrera, PM., 2006. Usi e tradizioni della flora italiana. Medicina popolare ed etnobotanica. Roma: Aracne.

Honfo, F.G., Akissoe, N., Linnemann, A.R., Soumanou, M., Van Boekel, M.A.J.S., 2014. Nutritional composition of shea products and chemical properties of shea butter: a review. Crit. Rev. Food Sci. Nutr. 54: 673-686.

Hori, I., Nihei, K.I., Kubo, I. 2004. Structural criteria for depigmenting mechanism of arbutin. Phytother. Res. 18:475-9.

Imokawa, G., Ishida, K., 2015. Biological mechanisms underlying the ultraviolet radiation-induced formation of skin wrinkling and sagging I: reduced skin elasticity, highly associated with enhanced dermal elastase activity, triggers wrinkling and sagging. Int. J. Mol. Sci. 16:7753-75.

Khare CP., 2004. Indian herbal remedies: rational Western therapy, ayurvedic, and other traditional usage, Botany. Khare CP (Ed), Springer Verlag, Berlin Heidelberg.

Korkmaz, B., Horwitz, M.S., Jenne, D.E., Gauthier, F., 2010. Neutrophil elastase, proteinase 3, and cathepsin $\mathrm{G}$ as therapeutic targets in human diseases. Pharmacol. Rev. 62:726-59.

Liyanaarachchi, G.D., Samarasekera, J.K., Mahanama, K.R., Hemalal, K.D., 2018 Tyrosinase, elastase, hyaluronidase, inhibitory and antioxidant activity of Sri Lankan medicinal plants for novel cosmeceuticals. Ind. Crops Prod. 111:597-605.

This item was downloaded from IRIS Università di Bologna (https://cris.unibo.it/)

When citing, please refer to the published version. 
Mandrone, M., Scognamiglio, M., Fiorentino, A., Sanna, C., Cornioli, L., Antognoni, F., Bonvicini, F., Poli, F., 2017. Phytochemical profile and $\alpha$-glucosidase inhibitory activity of Sardinian Hypericum scruglii and Hypericum hircinum. Fitoterapia 120:184-193.

Melzig, M.F., Löser, B., Ciesielski, S. 2001. Inhibition of neutrophil elastase activity by phenolic compounds from plants. Pharmazie 56:967-70.

Mukherjee, P.K., Maity, N., Nema, N.K., Sarkar, B.K., 2011. Bioactive compounds from natural resources against skin aging. Phytomedicine 19:64-73.

Nadembega, P., Boussim, J.I., Nikiema, J.B., Poli, F. and Antognoni, F., 2011. Medicinal plants in baskoure, kourittenga province, Burkina Faso: an ethnobotanical study. J. Ethnopharmacol. 133: 378395.

Ndukwe, I.G., Amupitan, J.O., Isah, Y., Adegoke, K.S., 2007. Phytochemical and antimicrobial screening of the crude extracts from the root, stem bark and leaves of Vitellaria paradoxa (GAERTN. F). Afr. J. Biotechnol. 6:16.

Pillaiyar, T., Manickam, M., Namasivayam, V., 2017. Skin whitening agents: Medicinal chemistry perspective of tyrosinase inhibitors. J. Enzyme Inhib. Med. Chem. 32:403-25.

Rittié, L., Fisher, G.J., 2002. UV-light-induced signal cascades and skin aging. Ageing Res. Rev. 1: 705-720.

Rodríguez-Pérez, C., Quirantes-Piné, R., Amessis-Ouchemoukh, N., Madani, K., Segura-Carretero, A., Fernández-Gutierrez, A., 2013. A metabolite-profiling approach allows the identification of new compounds from Pistacia lentiscus leaves. J. Pharm. Biomed. Anal. 77:167-174.

This item was downloaded from IRIS Università di Bologna (https://cris.unibo.it/)

When citing, please refer to the published version. 
Sanna, C., Rigano, D., Corona, A., Piano, D., Formisano, C., Farci, D., Franzini, G., Ballero, M., Chianese, G., Tramontano, E., Taglialatela-Scafati O., Esposito F., 2018. Dual HIV-1 reverse transcriptase and integrase inhibitors from Limonium morisianum Arrigoni, an endemic species of Sardinia (Italy). Nat Prod Res, DOI: 10.1080/14786419.2018.1434649

Sanna, C., Scognamiglio, M., Fiorentino, A., Corona, A., Graziani, V., Caredda, A., Cortis, P., Montisci, M., Ceresola, E.R., Canducci, F., Poli, F., Tramontano, E., Esposito, F. 2018. Prenylated phloroglucinols from Hypericum scruglii, an endemic species of Sardinia (Italy), as new dual HIV-1 inhibitors effective on HIV-1 replication. PloS One, 13:e0195168.

Sahu, R.K., Roy, A, Matlam, M, Deshmukh, V.K., Dwivedi, J., Jha, K., 2013. Review on skin aging and compilation of scientific validated medicinal plants, prominence to flourish a better research reconnoiters in herbal cosmetic. J. Med. Plant 7:1-22.

Slominski, A., Tobin, D. J., Shibahara, S., Wortsman, J., 2004. Melanin pigmentation in mammalian skin and its hormonal regulation. Physiol. Rev. 84: 1155-1228.

Thring, T.S., Hili, P., Naughton, D.P., 2009. Anti-collagenase, anti-elastase and anti-oxidant activities of extracts from 21 plants. BMC Complement. Altern. Med. 9:27.

Venditti, A., Mandrone, M., Serrilli, A.M., Bianco, A., Iannello, C., Poli, F., Antognoni, F., 2013. Dihydroasparagusic acid: antioxidant and tyrosinase inhibitory activities and improved synthesis. J. Agric. Food Chem. 61:6848-55.

Wittenauer, J., Mäckle, S., Sußmann, D., Schweiggert-Weisz, U., Carle, R, 2015. Inhibitory effects of polyphenols from grape pomace extract on collagenase and elastase activity. Fitoterapia 101:179187.

This item was downloaded from IRIS Università di Bologna (https://cris.unibo.it/)

When citing, please refer to the published version. 
Xing, X., Yang, X., Cao, Y., 2016. Study of Ellagic Acid as a Natural Elastase Inhibitor by Spectroscopic Methods. Appl. Spectrosc. 83.

\section{Figures captions}

Fig. 1. IC50 values of elastase inhibition (A) and IC50 values of tyrosinase inhibition (B) obtained for the most active extracts. Different letters within the same assay indicate significant differences in ANOVA test $(P<0.05)$. Results are expressed ad means \pm SD of three independent experiments.

$\mathrm{Ai}=$ Azadirachta indica; $\mathrm{AuL}=$ Arbutus unedo (leaves); $\mathrm{Csa}=$ Cistus salvifolius; $\mathrm{C}=$ Cochlospermum tinctorium; Cym=Cistus monspeliensis; Cyh=Cytinus hypocistis; $\mathrm{Hh}=$ Hypericum hiricinum; Hs=Hypericum scruglii; Ks=Khaya senegalensis; Lm=Limonium morisianum; McF=Myrtus communis (frutits); $\mathrm{McL}=$ Myrtus communis (leaves); Pit=Pistacia terebinhtus; $\mathrm{PIF}=$ Pistacia lentiscus (fruits); PIL=Pistacia lentiscus (leaves); $\mathrm{VpL}=$ Vitellaria paradoxa (leaves); $\mathrm{VpR}=$ Vitellaria paradoxa (roots).

Fig. 2. A: Correlation between the total phenolic content and the percentages of enzymatic inhibitions. Total phenolic content is expressed in $\mathrm{mg}$ GAE/g. For elastase $r 2$ was: 0.06207 and $P$ value: 0.0124 , while Pearson coefficient $(r): 0.2491$. For tyrosinase $r 2$ was: $0.1249 ; P$ value: 0.0003 and $r$ : 0.3535. B: Correlation between the total flavonoid content and the percentages of enzymatic inhibitions. Total flavonoid content is expressed in $\mathrm{mg}$ RE/g. For elastase $r 2$ was: $0.07369, P$ value: 0.0063 and $r: 0.2715$. For tyrosinase $r 2$ was: $0.07438, P$ value: 0.0060 and Pearson coefficient: 0.2727 .

This item was downloaded from IRIS Università di Bologna (https://cris.unibo.it/)

When citing, please refer to the published version. 
This item was downloaded from IRIS Università di Bologna (https://cris.unibo.it/)

When citing, please refer to the published version. 